\title{
Iron status in metabolic syndrome
}

\author{
Mohammad Abdul-Gaffor AL-Kataan \\ Department of Clinical Pharmacy, College of Pharmacy, University of Mosul
}

$$
\frac{\text { Received }}{9.1 \cdot .+11} \quad \frac{\text { Accepted }}{r .11 . r \cdot 1 r}
$$

\begin{abstract}
Objectives: This study aimed to determine the changes in iron status in MSindividuals and to determine the effects of sex on iron status in MS individuals.
\end{abstract}

Patients and methods: Fifty individuals ( $r \cdot$ males and $r \cdot$ females) had at least $r$ criteria of metabolic syndrome according to WHO criteria, and other fifty apparently healthy individuals ( $r \cdot$ males and $r \cdot$ females) considered to be control group. Fasting blood samples were taken from the patient and control groups and analysed for serum iron, ferritin, glucose and triglycerides.

Results: Serum iron, serum ferritin, glucose, triglycerides and saturation \% showed significant increase in MS individuals $(p<\bullet \bullet$ ) than control individuals, while serum HDL-C showed significant decrease in MS than in control $(p<\cdot .0)$. Serum ferritin showed a significant increase in male individuals with MS than in female individuals $(p<\bullet . \cdots)$, while serum HDL-C showed a significant reduction in male with MS than in female with MS $(p<\cdot \cdot \cdot)$.

Conclusion: Metabolic syndrome caused significant changes in patient iron status parameters. Serum ferritin was significantly less than males.

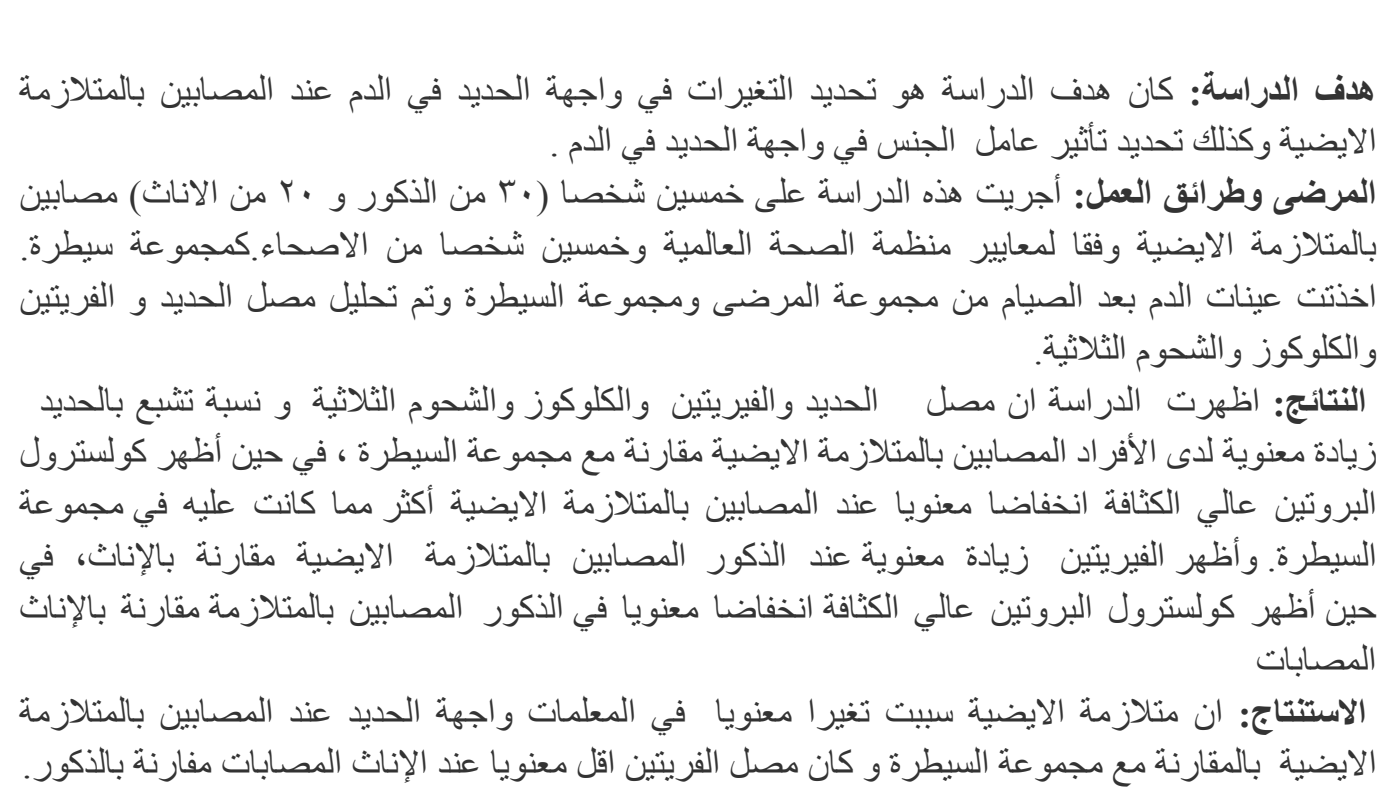

W etabolic syndrome (MS) is a all over the world in both developed and developing countries as in Iraq. According to the National cholesterol education program Adult Treatment 
Panel-III (ATP III) guideline define MS: as any subject with at least three of the following criteria: $\mathrm{BMI} \geq r$. $\mathrm{kg} / \mathrm{m}^{r}$, serum triglyceride $(\mathrm{TG}) \geq 10$. $\mathrm{mg} / \mathrm{dL}$, low serum high density lipoprotein $(\mathrm{HDL}-\mathrm{C}) \leq \varepsilon \cdot \mathrm{mg} / \mathrm{dL}$ in male and $\leq 0 \cdot \mathrm{mg} / \mathrm{dL}$ in female, blood pressure $\geq 1 \% \cdot / 10 \mathrm{~mm} \mathrm{Hg}$ and fasting serum glucose $(\mathrm{S} . \mathrm{G}) \geq 11 \cdot \mathrm{mg} / \mathrm{dL}$ '.

Metabolic syndrome may be related to changes in serum ferritin, iron and transferrin. Although ferritin is an indicator of cellular iron store in healthy subject, it provides little information on iron turnover in the body. ',

Transferrin is transporting protein (Shuttle protein) mainly synthesized in the liver and its principle role is the transport of ionic-iron to the liver, spleen and bone marrow. ${ }^{\top}$ Transferrin level rises in iron overload and falls with iron depletion status.

MS is associated with hyperglycemia and liver abnormality in addition to low grade inflammatory reaction, which may cause changes in serum iron and iron transporting proteins.

This study was conducted to determine the changes in iron status in MS individuals compared with the controls, and the effects of sex on iron status in MS individuals.

\section{Materials and methods}

This study was conducted in the period from January through September $r .11$ in Private internal medicine clinics in Al-Drkzilea area, Mosul. This study received approval from ethics and scientific committee in the department of Clinical Pharmacy, University of
Mosul. Fifty MS-individuals ( $r \cdot$ males and $r$. females) had at least $r$ criteria of metabolic syndrome according to WHO criteria', and other fifty apparently healthy individuals ( $r$. male and $r \cdot$ female) were considered to be the control group.

Blood samples $\left({ }^{\circ} \mathrm{ml}\right)$ were taken from the patient and control groups for analyses. Serum fasting glucose was assayed by glucose oxidase/peroxidase colorimetric method ${ }^{\natural}$. High density lipoprotein-cholesterol (HDL-C) was measured by Lopez-Virella method ${ }^{\vee}$ and triglycerides (TG) were measured by Fossati-enzymatic method ${ }^{\wedge}$. Serum iron was estimated by using Ferrozine method ${ }^{9}$. Serum ferritin was estimated by trubidimetric latex immunoassay'. Serum transferring was measured by using immunological trubidimetric method"'. Total iron binding capacity (TIBC) was measured by modification in Ransays method 'r, while transferrin saturation \% (Sat.\%) was obtained by the following equation ${ }^{1 r}$ :

Saturation $\%=$ serum iron $/$ total iron binding capacity $* 1 \ldots$

Data are presented as mean $\pm \mathrm{SD}$, unpaired t-test was used to compare between parameters, $p<. .0$ was considered significant.

\section{Results}

This study revealed that serum iron, serum ferritin, glucose, triglycerides and trasferrin saturation \% showed significant increase in MS individuals $(p<\cdot .0)$ compared with the controls, while serum HDL-C showed significant decrease in MS than controls $(p<\cdot \cdot 0)$ as shown in Table '. 
Table 1: Total serum iron status parameters in metabolic syndrome (MS) individuals and controls

\begin{tabular}{|c|c|c|}
\hline Parameter & $\begin{array}{c}\text { Control } \\
n=0 .\end{array}$ & $\begin{array}{c}\text { MS } \\
n=0 .\end{array}$ \\
\hline Serum iron $(\mu \mathrm{g} / \mathrm{dL})$ & $7 \cdot .90 \pm \Lambda . Y V$ & $\wedge \vee . \leqslant \pm 17.0 * * *$ \\
\hline Transferrin $(\mathrm{mg} / \mathrm{dL})$ & $r \cdot r \pm Y T$ & $19 \lambda \pm r \cdot$ \\
\hline Ferritin $(\mu \mathrm{g} / \mathrm{dL})$ & $90.9 \pm r \wedge$ & $119 . V_{ \pm} \Sigma * *$ \\
\hline Fasting serum glucose (mg/dL) & $9 T . r 0_{ \pm} 0 . V r$ & $110.9 \pm 1 \cdot * * *$ \\
\hline Triglycerides $(\mathrm{mg} / \mathrm{dL})$ & $9 r . \leqslant 0 \pm \lambda . r$ & $1 \pi r .1 \pm r r . Y * *$ \\
\hline $\mathrm{HDL}-\mathrm{C}(\mathrm{mg} / \mathrm{dL})$ & $\varepsilon \wedge . \cdot 0_{ \pm} \varepsilon . \wedge \varepsilon$ & 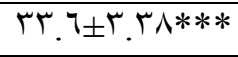 \\
\hline $\mathrm{TIBC}(\mu \mathrm{g} / \mathrm{dL})$ & ror \pm Tr.r & $r \leqslant V . r \pm r V . r$ \\
\hline Sat. \% & $r r .70 \pm 1.90$ & $r 0 . V_{ \pm}$ๆ. $) \leqslant * * *$ \\
\hline
\end{tabular}

TIBC: Total iron binding capacity, Sat.\%: transferrin saturation percentage

$* p<\cdot . \bullet, * * p<\cdots 1, * * * p<\cdot . \cdots 1$

Table r: Total iron status parameters in males and females with metabolic syndrome

\begin{tabular}{|c|c|c|}
\hline Parameter & $\begin{array}{l}\text { Male } \\
n=r .\end{array}$ & $\begin{array}{c}\text { Female } \\
n=r .\end{array}$ \\
\hline Serum iron $(\mu \mathrm{g} / \mathrm{dL})$ & $\wedge \wedge\urcorner. \pm 1 Y$ & $\wedge \neg . r \pm Y$. \\
\hline Transferrin $(\mathrm{mg} / \mathrm{dL})$ & $190 . \wedge \pm Y \varepsilon .1$ & 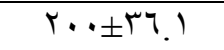 \\
\hline Ferritin $(\mu \mathrm{g} / \mathrm{dL})$ & $10 V .1 \pm Y A$ & Ar.r. \pm Ir.q*** \\
\hline Serum glucose (mg/dL) & $11 Y \pm 1 \cdot .7$ & $1.9 . \vee \pm 9.1$ \\
\hline Triglycerides $(\mathrm{mg} / \mathrm{dL})$ & $11 \leqslant . V \pm r \leqslant .7$ & $1.9 .0 \pm Y Y . Y$ \\
\hline HDL-C & $r 1.0 \pm r .09$ & ro. $V_{ \pm} Y . V_{0 * *}$ \\
\hline TIBC $(\mu \mathrm{g} / \mathrm{dL})$ & $r \leq 9 . \wedge \pm \leqslant 0$ & $r \leq \leqslant .0 \pm r$. \\
\hline Sat. \% & $r 0.9 \pm \lambda . \cdot r$ & $r 0.0 \pm r . \wedge 9$ \\
\hline
\end{tabular}

TIBC: Total iron binding capacity, Sat.\%: transferrin saturation percentage

$* p<\cdot . \bullet, * * p<\cdot \cdot 1, * * * p<\cdot . \cdots 1$

Serum ferritin showed a significant increase in male individuals with MS than females $(p<\because \cdots)$, while serum HDL-C showed a significant reduction in males with MS than in females $(P<\cdot \cdot)$ as shown in Table r.

\section{Discussion}

In the present study, serum iron showed significant increase in MS patient, these result are consistent with other studies ${ }^{r}$ and this increase may be due to increases in the intestinal absorption of this element. High serum iron can also related to the proinflammatory process that usually associated with $\mathrm{MS}^{\circ}$ (as we exclude other causes of inflammation).

In this study, serum ferritin which is an acute phase protein showed significant increase in MS individuals, the increase in serum ferritin was related to iron body store $^{10,14}$. In addition, some researchers considered serum ferritin as component of $\mathrm{MS}^{\mathrm{\prime}}$. 
The study showed no significant changes in serum transferrin between MS patient compared to controls and this consistent with results described by other workers ${ }^{1 \wedge}, 19$, while other studies showed a significant change in serum transferrin in MS individuals ${ }^{r, 1}$.

TIBC refer to the amount of iron that could be bound to saturating transferrin other minor iron binding protein present in the serum or plasma sample this normally form one third of iron binding sites on transferrin ${ }^{15}$. In this work TIBC showed no significant change between MS individuals compared to controls and this can be related to non-significant changes in serum transferrin level between MS.

Serum transferrin saturation percentage showed significant increase in MS compared with controls and this increase in the percentage may occurred due to significant increase in the serum iron showed in MS individuals $^{r \cdot, r}$.

Serum ferritin showed significant decrease in female patients compared to male patients and this consistent with other studies that relate this reduction to menstrual bleeding in female patients that lead to significant reduction in serum iron body store which reflected as iron deficiency anemia in such individuals ${ }^{1 r, 1 \wedge, 19}$.

Serum glucose and serum triglycerides showed significant increase in MS compared to controls, while serum HDL-C showed significant decrease in male patients when compared to female patients and this may be due to insulin resistance and female sex hormones ${ }^{1 r}$.
In conclusion, metabolic syndrome can cause significant changes in iron status parameters. Serum ferritin in females was significantly lower than that in males.

\section{References}

1- Grundy S, Bremer B, Cleeman J, Smith S. Defention of Metabolic syndrome. Report of the national heart, lung and blood institute /American heart association conference on scientific issue related to definition. Circulation

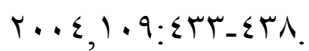

r. Martin B, Wathrins J, Ramsey J. Evaluating metabolic syndrome in medical physiology laboratory. Adv Physicl Edue r.. $\xi_{;} \wedge_{:} / 190_{-}$ 191.

r- Huebers A, Hueber E, Csiba E, et al. The significance of transferrin for intestinal iron absorption.

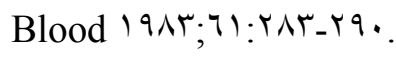

ะ- Andrews C, Levy E. Iron is hot: an update on the pathophysiology of haemochromatosis. Blood 1991; $9 Y: 1 \wedge \leqslant 0.01$.

○- Swaminthan S, Alam M, Fonseca $\mathrm{V}$, Shah S. The role of iron in diabetes and its complication. Diabetes care r..v; $;$ : 19 q צ_ $19 r$ r.

7. Halliwell B, Gutteridge C. Role of free radicals and catalytical metal iron in human disease an over

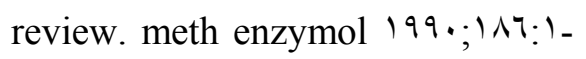
10.

V - Lotta JA, Turner K. Evaluation of trinder's glucose oxidase method for measuring glucose in serum and urine. Clin Chem 19v0; Y1:1 vo _IVT. 
^- Lopez-Virella MF, Stone P, Colwell JA. Cholesterol determination in high density lipoproteins separated by three different methods. Clin Chem

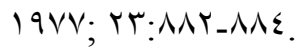

9. Fossti P, Prencipe L . Serum triglycerides determination colorimtrically with an enzyme that produces hydrogen peroxides. Clin

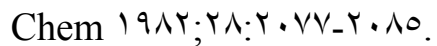

1.-Stooky L. Ferrozine. A new spectrophatometric reagent for iron. Anal Chem $19 \vee \cdot ; \xi r: \vee \vee q_{-} \vee \wedge 1$.

1)-Bemard A, Laumerys R. Trubidimetric latex immunoassay for serum ferritin. $\mathbf{J}$ immunol

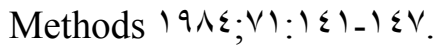

IT-Krautzer J. An immunological trubidimetric method for serum transferring determination. J Clin Chem Clin Biochem 19vч;1 $:$ : .1. $\varepsilon \cdot 7$.

Ir-Baadenhuijsen H, Deimanu G. Modification in Ransays method for correct measurement of total iron binding capacity. Clin Chem Acta 1911; 1V7:9_17.

I $\leqslant$-Bishop M, Fody E, Schoeff L. Clinical Chemistry : Procedures, Principles and Correlation. Lippincott Williams New York, USA. r..0:r.r-r.r.

10-Gabay C, Kushner I. Acute phase proteins and others system responses to inflammation. $\mathrm{N}$ Engl

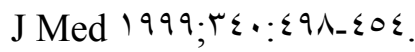

17 - Jehn M, Clark J, Gwallar E. Serum ferritin and risk of the metabolic syndrome in US Adults. Diabetes Care $r \ldots \leqslant ; r V: r \leqslant r-r \Lambda$.

IV-Bozzini C, Girelli D, Olivier O, et al. Prevalence of body iron excess in metabolic syndrome. Diabetes Care $r \cdot . \cdot 0 ; \wedge: r \cdot T)-r \cdot r$.

IN- Vari I, Balkan B, Kettanch A, et al.

Fumeron F. Ferritin and transferring are associated with metabolic syndrome abnormalities and their change over time in general population. Diabetes Care

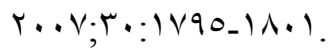

19-Fernandes-Real M, Ricart-Engel $\mathrm{W}$, Arroyo E, et al Serum ferritin as a component of the insulin resistance syndrome Diabetes Care 19A1; YI:Tr-TA.

$r$--Fumeron F, Pean F, Driss F, et al. Ferritin and transferring are both predictive of the oncet of hyperglycemia in man and women over $r$ years the data from an epidemiological study on the insulin resistance syndrome (DESIR) study. Diabetes Care r.. T;rq:r.9.-r. $9 \varepsilon$.

Y)-Mainous III A, King D, Person Wss, Garr D. Is an elevated serum transferrin saturation associated with the development of diabetes. Journal of family practice r...r;01:9rr_qru. 